\title{
(1000) ПРОЦЕСИ
}

doi: $10.15407 /$ dse2016.02.011

УДК 314.114:33(477)

JEL Classification: J10, J 11

\section{І.О. КУРИЛО}

д-р екон. наук, проф.

Інститут демографії та соціальних

досліджень ім. М.В. Птухи НАН України

01032, Україна, Київ, бул. Тараса Шевченка, 60

E-mail: kurilo2005@yandex.ru

\section{В.П. ДУМАНСЬКА}

канд. екон. наук, старш. наук. співроб.

Інститут демографії та соціальних

досліджень ім. М.В. Птухи НАН України

E-mail: vita.dumanska@gmail.com

\section{ОЦІНКА ПОВ'ЯЗАНИХ ІЗ БАТЬКІВСТВОМ ПЕРЕВАГ TA ВТРАТ ЗАРОБITКУ В УКРАЇНI}

\begin{abstract}
Проаналізовано фінансові втрати або переваги від батьківства в Україні. Із використанням економетричних моделей визначено відмінності у заробітках жінок та чоловіків, які мають дітей різного віку, а також залежно від соціально-демографічних ознак батьків та характеристик їхьої зайнятості. Встановлено, що наявність малолітніх дітей (віком до 3 років) призводить до найбільших втрат у заробітках жінок - від 25 до 39 \%; жінки, які мають дітей дошкільного віку, в Україні отримують трудові доходи на 8-12\% менші, ніж матері старших дітей. Результати розрахунків засвідчили значущі переваги високоосвічених батьків щодо рівня трудового доходу - відносні фінансові втрати від батьківства в осіб з вищою освітою суттєво менші, ніж у батьків / матерів без вищої освіти. Виявлено також диференціацію фінансових втрат / переваг батьківства між зайнятими з різним рівнем трудового доходу: значущі відносні втрати у заробітку характерні саме для тих матерів, які зайняті на низькооплачуваних роботах. Згідно з результатами дослідження, специфіка трудової діяльності осіб, які працюють у різних секторах економіки або відрізняються за статусом зайнятості, також зумовлюе відмінності щодо втрат унаслідок батьківства, при иьому окремі види діяльності та позиції у сфері зайнятості в Україні можна вважати недостатньо «дружніми» до працівників з дітьми.
\end{abstract}

Ключові слова: батьківство, материнство, фінансові втрати від материнства, фінансові переваги від батьківства, гендерна диференціація трудових доходів, оцінка фінансових втрат, створення умов для поєднання зайнятості з батьківством.

\section{И.А. Курило}

д-р экон. наук, проф.

Институт демографии и социальных

исследований им. М.В. Птухи НАН Украины

01032, Украина, Киев, бул. Тараса Шевченко, 60

E-mail: kurilo2005@yandex.ru 


\section{В.П. Думанская}

канд. экон. наук, старш. науч. сотрудник

Институт демографии и социальных

исследований им. М.В. Птухи НАН Украины

E-mail: vita.dumanska@gmail.com

\section{ОЦЕНКА СВЯЗАННЫХ С ОТЦОВСТВОМ ПРЕИМУЩЕСТВ И ПОТЕРИ ЗАРАБОТКА В УКРАИНЕ}

Проанализированы финансовые потери вследствие родительства в Украине. С использованием эконометрических моделей определены различия в трудовых доходах отиов и матерей, имеющих детей разного возраста, а также в зависимости от социально-демографических признаков родителей и характеристик их занятости. Установлено, что наличие малолетних детей (в возрасте до 3 лет) приводит к наибольшим потерям в заработках женшин - от 25 до 39 \%; $y$ женщин, имеющих детей дошкольного возраста, трудовые доходы на 8-12\% ниже, чем у матерей старших детей. Результаты расчетов показали значимые преимущества высокообразованных родителей по уровню трудового дохода - финансовые потери от родительства у лии с высшим образованием существенно меньше, чем у матерей / отиов без высшего образования. Выявлена также дифференциация финансовых по-терь / преимуществ из-за родительства между занятыми с разным уровнем трудового дохода: значимые относительные потери характерны именно для тех матерей с малолетними детьми и детьми дошкольного возраста, которые заняты на низкооплачиваемых работах. Согласно результатам исследования, специфика трудовой деятельности лии, работающих в разных секторах экономики или имеющих разный статус занятости, также обусловливает отличия в уровне потерь вследствие родительства, при этом отдельные виды деятельности и позиции в сфере занятости в Украине можно считать недостаточно «дружественными» к работникам с детьми.

Ключевые слова: родительство, материнство, финансовые потери от материнства, финансовые преимущества родительства, гендерная дифференциация трудовых доходов, оценка финансовых потерь, создание условий для сочетания занятости с родительством.

\section{I.O. Kurilo}

Dr. Sc. (Economics), Prof.

Ptoukha Institute for Demography and Social Studies

of the National Academy of Science of Ukraine

01032, Ukraine, Kyiv-32, Taras Shevchenko Blvd., 60

E-mail: kurilo2005@yandex.ru

\section{V.P. Dumanska}

$\mathrm{PhD}$, Senior research fellow

Ptoukha Institute for Demography and Social Studies

of the National Academy of Sciences of Ukraine

01032, Kyiv-32, Taras Shevchenko Blvd., 60

E-mail: vita.dumanska@gmail.com

\section{ESTIMATION OF PARENTHOOD WAGE PENALTIES AND BENEFITS IN UKRAINE}

The article outlines parenthood wage penalties and benefits in Ukraine. A wage gap among parents with children of different ages was determined with using of econometric models considering social-demographic characteristics and employment status of parents. Mothers of children under the age of 3 years earn from 25 to $39 \%$ less than mothers of children of school age. Wage gap for those who have children of pre-school age (3-6 years) is 8-12 $\%$. Calculations demonstrate significant wage benefits for parents with high education. Such categories face lower wage penalties in comparison with low-educated parents. There is a difference in financial penalties and benefits among parents with low and high income: the most significant penalties apply to low-income women workers. Parental wage penalties apply also to people employed in different economic sectors and with different employment status. At the same time, some jobs in Ukraine are not «family friendly». The research results stress the necessity of social policy, which creates opportunities for beneficial combination of parenthood and employment. 
Key words: parenthood, motherhood, financial costs of motherhood, motherhood wage penalties, financial benefits of parenthood, gender gap of labor income, estimation of financial losses, creating conditions to combine employment with parenthood.

Вступ. Батьківство у сучасному суспільстві зберігає риси феномену, який асоціюється із самодостатніми і універсальними людськими цінностями, несе значне смислоутворювальне навантаження щодо людського життя. Водночас у ході трансформаціїі форм і функцій батьківства, а також низки суміжних соціальних та економічних інститутів (освіти, соціального захисту, ринку праці тощо) повсякчас посилюється конкуренція між потребами, пов’язаними із батьківством, та тими, що «вплетені у тканину» економічної діяльності й тісніше пов'язані з особистісною самореалізацією, з гедоністичними прагненнями тощо. Зі зростанням ролі людського капіталу в економічному відтворенні та посиленням значущості інвестування у нього, починаючи з дитинства, актуалізуються й певні економічні проблеми щодо реалізації батьківських функцій, збільшується вплив економічних чинників на репродуктивну поведінку, зазнають трансформацій практики поєднання професійної зайнятості з батьківством/материнством.

Цілком закономірним у даному контексті стало відповідне пожвавлення дослідницького інтересу до різних демоекономічних аспектів проблематики батьківства, як-от: до аналізу економіко-трудових факторів та обмежень при прийнятті рішення про народження дитини; оцінки альтернативних витрат, пов'язаних із виконанням материнських функцій (зокрема, доглядом за малолітніми дітьми, піклуванням та вихованням); визначення витрат на дітей, матеріального становища сімей з дітьми та якісних характеристик дітей тощо. Ще одним із питань, яке видається менш глобальним, але практично значущим для вдосконалення соціальної політики у контексті створення умов для поєднання зайнятості з батьківством, досягнення гендерної рівності тощо, є проблема скорочення заробітків працюючих осіб у зв’язку з батьківством / материнством (в англомовному варіанті ця проблема найчастіше позиціонується як motherhood wage penalty).

Аналіз наявних досліджень. Питання фінансових втрат, зумовлених батьківством, особливо активно досліджують у США. Численні наукові розвідки підтверджують диференціацію доходів серед зайнятих матерів та жінок без дітей. Така різниця, за інших рівних умов, становить від $2 \%$ [9] до $9 \%$ [14] за наявності однієї дитини. Причому деякі науковці довели, що відповідна різниця може сягати і 20 \% [6]. Встановлено також, що менших відносних втрат зазнають жінки, які народжують дитину пізніше.

Фінансові втрати від батьківства практично відсутні в Данії [5] та Швеції [4], у цих країнах наявність дітей практично не впливає на розмір заробітної плати. Аналіз цієї проблеми стосовно Австралії дає доволі суперечливі результати: деякі науковці, спираючись на результати власних досліджень, стверджують, що заробітна плата жінок з дітьми не відрізняється від заробітної плати жінок, у яких немає дітей [15], натомість інші свідчать, що фінансові втрати від материнства становлять 4 \% [7].

Цінними є результати порівняльного аналізу гендерної диференціації в оплаті праці та фінансових втрат від материнства у країнах Європейського союзу. Встановлено, що в 13 країнах (Кіпр, Ірландія, Словаччина, Німеччина, Бельгія, Словенія, Польща, Італія, Угорщина, Франція, Чехія, Португалія, Греція) диференціація в оплаті праці жінок зумовлена радше гендерною дискримінацією, ніж материнством. Водночас у Литві та Люксембурзі фінансові втрати від материнства дуже високі і значно 
перевищують показник гендерної диференціації заробітної плати. У решті країн втрати від материнства відчутно менші і становлять від 9 до 21 \% [12].

Батьківство позначається на доходах не лише жінок, а й чоловіків. За результатами досліджень, доходи чоловіків, які перебувають у шлюбі та мають дітей, є вищими у порівняні з неодруженими та розлученими чоловіками без дітей. Американськими науковцями встановлено, що материнство призводить до втрати 5 \% заробітку порівняно з доходом бездітних жінок, а чоловіки, в яких є діти, заробляють на $9 \%$ більше, ніж чоловіки без дітей [10]. Доведено також, що одружені чоловіки заробляють більше, ніж одинаки [8]. Але стосовно чоловіків ця проблематика розроблена значно менше, ніж щодо жінок, у тому числі й через інформаційні обмеження, адже доволі часто трудову діяльність жінки обстежують разом з фертильністю, тоді як для чоловіків зазвичай отримують лише інформацію про шлюбний стан і значно рідше про наявність та кількість дітей.

Рівень фінансових втрат від батьківства практично не вивчений у країнах Східної Європи. Наявне дослідження, згідно з результатами якого матері в Росії у 20032005 рр. заробляли майже на 8 \% менше порівняно з жінками, в яких немає дітей, тоді як гендерна диференціація в оплаті праці становила близько 27 \% [2]. Крім того, можна згадати хіба що наукову роботу, присвячену тематиці, близькій до даної: на матеріалах лонгітюдного обстеження в Росії нещодавно досліджено вплив змін шлюбного стану на заробітки чоловіків [3].

В Україні наразі єдиним дослідженням фінансових втрат від материнства є праця О. Нізалової та Т. Слюсаренко. На основі даних ULMS ${ }^{1}$ за 1997-2004 рр. ними встановлено, що матері з однією дитиною заробляють в середньому на 6,5 \% менше,

Таблиия 1. Дослідження, присвячені визначенню втрат від батьківства у різних країнах

\begin{tabular}{|c|c|c|}
\hline Автори & Країна дослідження & Отримані результати \\
\hline Waldfogel, Jane (1997) & США & $\begin{array}{l}\text { Втрата від материнства при народженні } \\
\text { першої дитини }-4 \% \text {, при народженні 2-х } \\
\text { і більше дітей }-12 \%\end{array}$ \\
\hline $\begin{array}{l}\text { Lundberg, Shelly and Rose, } \\
\text { Elaina (2002) }\end{array}$ & США & $\begin{array}{l}\text { Жінки втрачають } 5 \% \text { заробітку з народ- } \\
\text { женням дитини, заробіток чоловіків-бать- } \\
\text { ків зростає на } 9 \%\end{array}$ \\
\hline $\begin{array}{l}\text { Livermore, T., Rodgers, J.R. } \\
\text { and Siminski, P. (2011) }\end{array}$ & Австралія & $\begin{array}{l}\text { Жінки втрачають } 4 \text { \% заробітку з народ- } \\
\text { женням дитини }\end{array}$ \\
\hline Kunze and Ejrnaes (2013) & Німеччина & $\begin{array}{l}\text { Жінки втрачають } 3-5,7 \text { \% заробітку за ко- } \\
\text { жен рік відпустки по догляду за дитиною }\end{array}$ \\
\hline $\begin{array}{l}\text { Síle Pádraigín O’Dorchai } \\
\text { (2006) }\end{array}$ & Країни СС & $\begin{array}{l}\text { Втрати від материнства - 9-21 \% заробіт- } \\
\text { ку залежно від країни }\end{array}$ \\
\hline $\begin{array}{l}\text { Arzhenovskiy, S., Artamono- } \\
\text { va D. (2007) }\end{array}$ & Росія & Втрата від материнства - 8 \% заробітку \\
\hline $\begin{array}{l}\text { Nizalova, Olena Y., Sliu- } \\
\text { sarenko Tamara (2013) }\end{array}$ & Україна & $\begin{array}{l}\text { Жінки втрачають } 6,5 \text { \% доходу з народ- } \\
\text { женням першої дитини, } 13,3 \% \text { - другої та } \\
\text { ще } 6,5 \% \text { - третьої та чергових дітей }\end{array}$ \\
\hline
\end{tabular}

Джерело: $[14,10,7,6,12,2,11]$.

${ }^{1}$ Ukrainian Longitudinal Monitoring Survey; останній раунд проведено у 2007 р. [13]. 
ніж жінки без дітей, а матері з двома дітьми мають заробіток на 13,3 \% менший. Встановлено також, що наявність кожної наступної дитини призводить до втрати майже 6,5 \% доходу [11].

Результати усіх вищезгаданих досліджень фінансових втрат від батьківства систематизовано нами в табл. 1.

Отже, натепер доведено, що в основному втрачають у заробітках жінки й такі втрати можуть сягати третини їхнього доходу у порівнянні з жінками без дітей. Основними чинниками нижчих заробітків жінок з дітьми є такі:

- після народження дитини жінки часто переривають трудову діяльність або переходять на неповну тривалість робочого часу, аби мати можливість доглядати за дітьми;

- часто матері надають перевагу роботі, яка дає змогу поєднувати материнство та зайнятість; така робота зазвичай є менш оплачуваною;

- догляд за дітьми та домашня праця виснажують жінок та знижують їх продуктивність на робочому місці, що, в свою чергу, зумовлює нижчі заробітки;

- серед роботодавців поширене упереджене ставлення до працівників з дітьми (особливо жінок), внаслідок чого вони мають нижчий рівень оплати праці.

Всі вищеназвані чинники мають місце і справляють певний вплив на зайнятість та заробітки жінок-матерів і в нашій країні.

Мета роботи. Враховуючи результати згаданої наукової розвідки щодо втрат від материнства в Україні, грунтованої на встановленні відмінностей між заробітками жінок без дітей та тих, які народили дітей, ми вирішили поглибити дослідження цього питання шляхом розгляду відмінностей у заробітках батьків та матерів, які мають дітей різного віку та тих батьків/матерів, які різняться за соціально-демографічними ознаками й характеристиками людського капіталу. Метою нашого дослідження стала оцінка фінансових втрат від батьківства в Україні - як втрат, які несуть жінки-матері, так і впливу батьківства на доходи чоловіків - у залежності від віку дітей та низки соціально-демографічних характеристик батьків - з використанням інструментарію економетричного моделювання за 2007 та 2012 pp.

Виклад основного матеріалу. Статистичною базою дослідження стали дані обстеження умов життя домогосподарств України (ОУЖД) за 2007 та 2012 рр. Ці роки для аналізу було обрано з огляду на відносну соціально-економічну та політичну стабільність: 2007 р. - як останній рік перед світовою фінансово-економічною кризою, 2012 р. - як передреволюційний.

Для оцінювання фінансових втрат від батьківства в Україні ми скористались методологією, запропонованою бельгійськими науковцями для оцінювання гендерних відмінностей в оплаті праці та втрат у заробітках, пов'язаних із батьківством, в європейських країнах [12].

До аналізованої сукупності було включено зайнятих осіб. У вибірці за 2007 рік до розрахунків та аналізу було залучено дані про 8466 осіб, у 2012 році - 7885 осіб.

Аналіз здійснено з застосуванням МНК на основі оцінки відмінностей заробітків жінок та чоловіків; матерів та батьків з дітьми різного віку. Використано рівняння виду:

$$
\log (W)=\beta X+\varepsilon,
$$

де $\log (W)$ - експонента середньомісячного трудового доходу (обидві статі; жінки; чоловіки); $X$ - незалежна змінна; $\varepsilon$ - похибка.

В оригінальній методиці залежною змінною є погодинна ставка оплати праці. На наш погляд, батьківство впливає не лише на заробітну плату, але й на інші доходи, пов’язані з трудовою діяльністю, тому ми пропонуємо для аналізу використовувати показник трудового доходу. Цей показник охоплює заробітну плату за основним 
місцем роботи, дивіденди, компенсаційні виплати, допомоги за основним місцем роботи, заробітну плату в натуральній формі за основним місцем роботи, заробітну плату на інших роботах у грошовій та натуральній формах, дохід від підприємницької діяльності, дохід від самостійної трудової діяльності, оплату праці на інших тимчасових роботах, а також виплату заборгованості з заробітної плати за місцем роботи й виплату заборгованості з заробітної плати за попереднім місцем роботи. Для України найбільш прийнятною характеристикою є середньомісячний дохід, а не погодинна ставка, з огляду на це ми розрахували показник середньомісячного трудового доходу. Тож залежною змінною в моделі став логарифм середньомісячного трудового доходу (логарифмування застосовано з метою зниження рівня варіації доходів).

Для аналізу використано такі незалежні змінні:

- демографічні: вік (від 18 до 59 років); шлюбний стан (особи, які ніколи не перебували у шлюбі; особи, які перебувають у шлюбі; післяшлюбний стан (розлучені та овдовілі, разом)); наявність та вік дітей (матері / батьки, які мають дітей віком до 3 років; дітей у віці від 3 до 6 років; від 6 до 18 років); тип поселення (велике місто; мале місто; село).

- характеристики зайнятості та людського капіталу: рівень освіти (особи з вищою освітою та особи без вищої освіти); стаж роботи (додатково використано квадрат стажу, роки); статус зайнятості (працюючі за наймом; підприємціроботодавці, самозайняті; безоплатно працюючі члени сім’і).

Описову статистику за основними змінними наведено у табл. 2, а результати розрахунків - у табл. 3 та 4 .

Таблиия 2. Характеристики масиву даних щодо зайнятих осіб, використаного для розрахунків

\begin{tabular}{|l|c|c|c|c|}
\hline \multirow{2}{*}{ Змінні } & \multicolumn{2}{|c|}{ Жінки } & \multicolumn{2}{|c|}{ Чоловіки } \\
\cline { 2 - 5 } & $\begin{array}{c}\text { середнє } \\
\text { значення }\end{array}$ & $\begin{array}{c}\text { стандартне } \\
\text { відхилення }\end{array}$ & $\begin{array}{c}\text { середнє } \\
\text { значення }\end{array}$ & $\begin{array}{c}\text { стандартне } \\
\text { відхилення }\end{array}$ \\
\hline \multicolumn{3}{|c|}{$\mathbf{2 0 0 7}$ рік } \\
\hline Стаж роботи & 17,90796 & 9,989612 & 17,12132 & 10,37662 \\
\hline Середньомісячний трудовий дохід & 706,9663 & 542,4579 & 959,009 & 649,697 \\
\hline $\begin{array}{l}\text { Логарифм середньомісячного трудового } \\
\text { доходу }\end{array}$ & 6,317496 & 0,8100201 & 6,589567 & 0,8679599 \\
\hline Вік & 41,29424 & 9,830662 & 40,408 & 10,6594 \\
\hline Число дітей у респондентів & 0,5467318 & 0,601936 & 0,5704002 & 0,648148 \\
\hline Чисельність респондентів & 4395 & & 4071 \\
\hline \multicolumn{3}{|c|}{$\mathbf{2 0 1 2}$ рік } & & \\
\hline Стаж роботи & 17,39869 & 9,962432 & 16,23616 & 10,29537 \\
\hline Середньомісячний трудовий дохід & 1541,554 & 897,792 & 1968,867 & 1294,724 \\
\hline $\begin{array}{l}\text { Логарифм середньомісячного трудового } \\
\text { доходу }\end{array}$ & 7,124874 & 0,7949975 & 7,331235 & 0,8434092 \\
\hline Вік & 42,01135 & 9,80212 & 40,4308 & 10,5992 \\
\hline Число дітей у респондентів & 0,5240175 & 0,6336212 & 0,5832589 & 0,7063872 \\
\hline Чисельність респондентів & 4069 & & 3816 \\
\hline
\end{tabular}

Джерело: ОУЖД за 2007 та 2012 рр. 


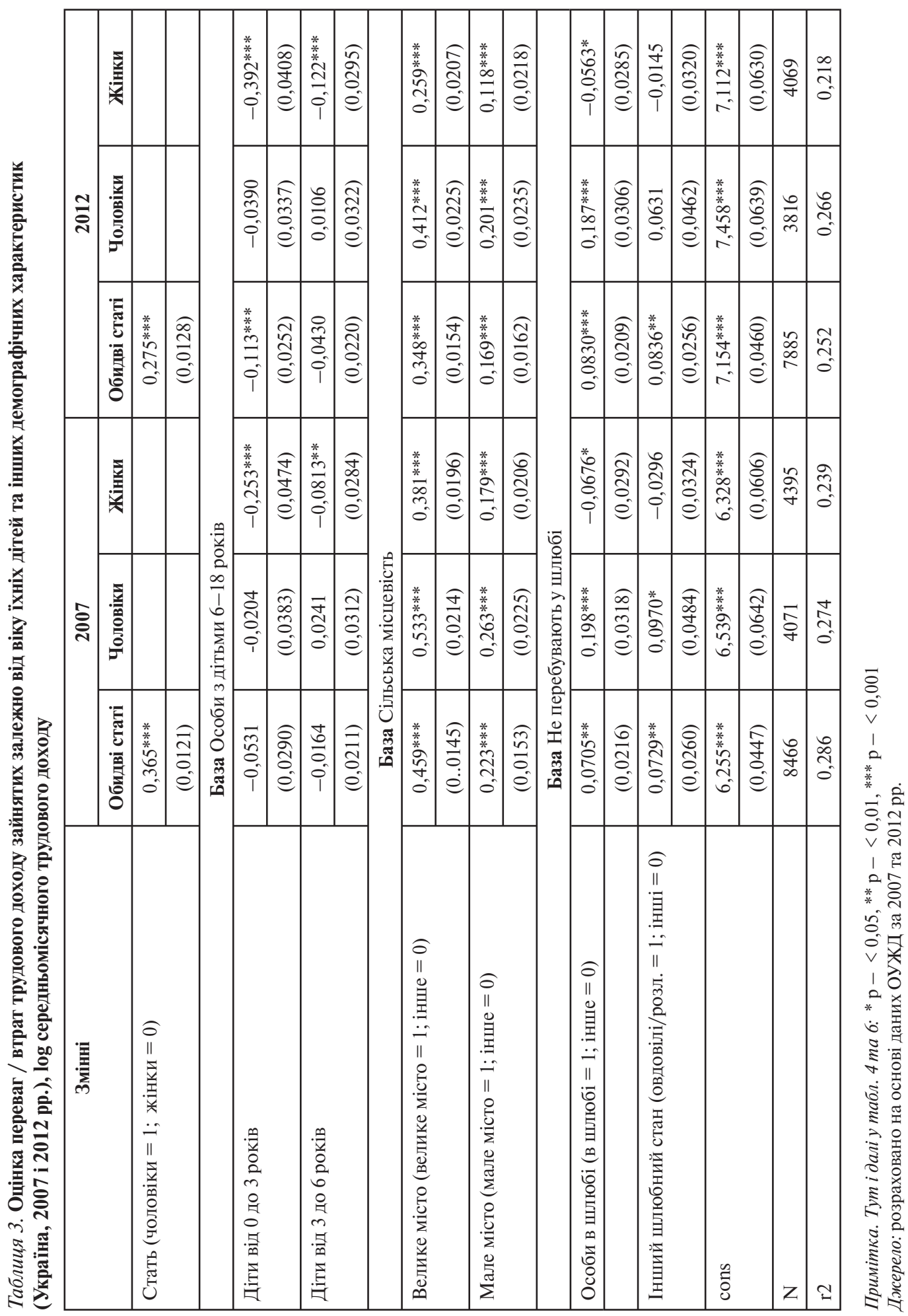




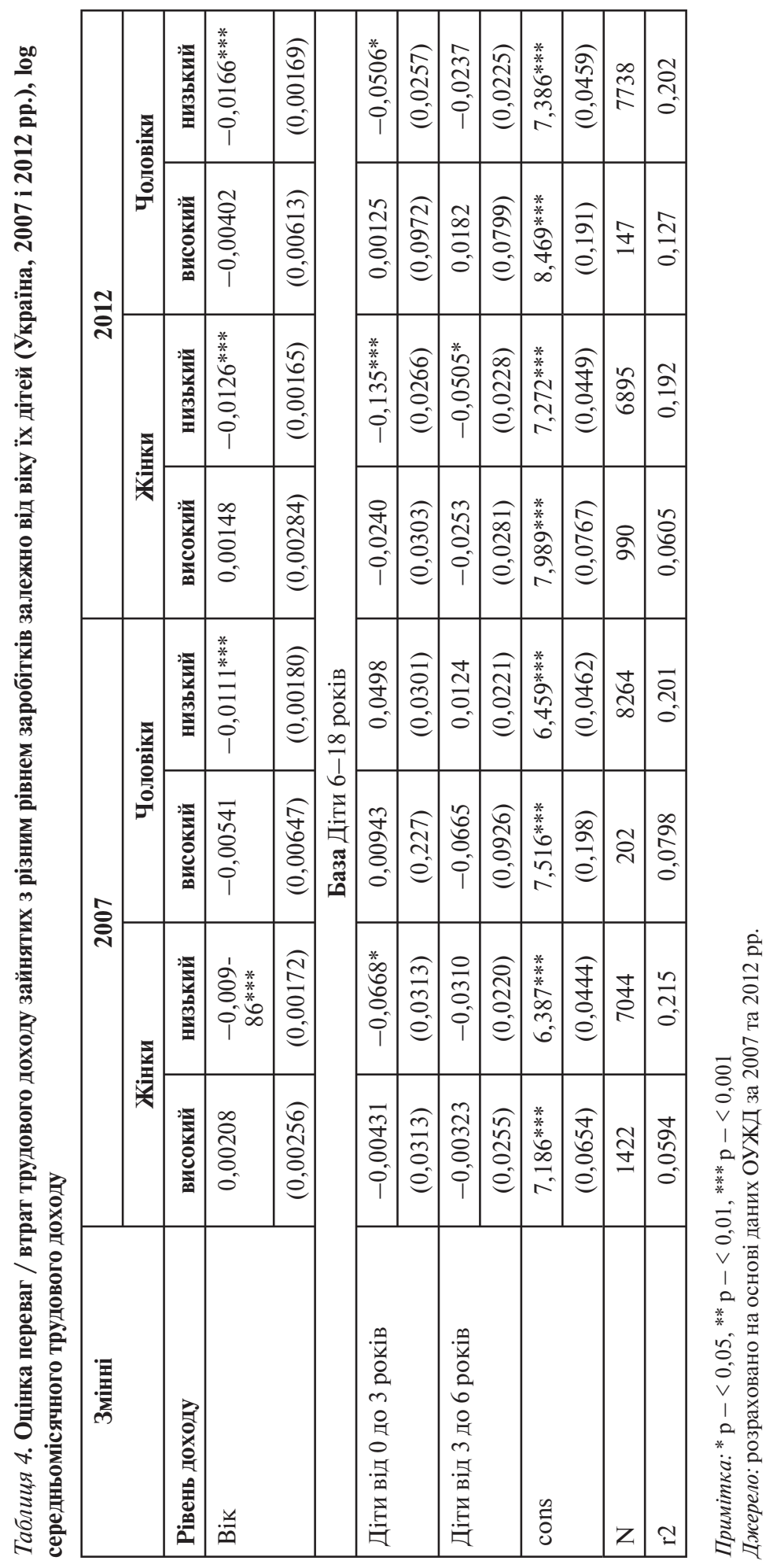


Згідно з результатами розрахунків, представленими у табл. 3, у 2007 р. загальний розрив між показниками середньомісячного трудового доходу чоловіків і жінок становив понад $36 \%$, а у 2012 р. - близько $28 \%$. Зазначимо, що окреслені зміни цілком відповідають напряму динаміки гендерного розриву в середній заробітній платі за даними офіційної статистики і зумовлені випереджувальними підвищенням у 2012 р. заробітної плати саме у низці бюджетних галузей, у яких зайняті переважно жінки. Результати розрахунків показують також, що зайняті особи, які мешкають у великих містах, заробляють на 35-45 \% більше у порівнянні з тими, хто живе у сільській місцевості (чоловіки ж у великих містах заробляли у середньому в півтора рази більше, ніж в селах). Жителі малих міст мали у середньому на чверть вищі трудові доходи, ніж жителі сіл.

Середньомісячний трудовий дохід осіб, які перебувають у шлюбі або перейшли в післяшлюбний стан, у нашій країні в середньому на 7-8 \% вищий, порівняно 3 тими, хто у шлюбі не перебував. Більш детальний розгляд відповідних відмінностей засвідчує, що перебування у шлюбі особливо помітно впливає на рівень доходу саме чоловіків ${ }^{2}$. Так, одружені чоловіки заробляють майже на 1/5 більше порівняно 3 тими, хто ніколи не перебував у шлюбі, при цьому щодо заміжніх жінок зафіксовано протилежне співвідношення, що є статистично значущим - жінки, які перебували в шлюбі, у досліджувані роки заробляли на 6-7 \% менше, ніж незаміжні.

Tрудовий дохід та вік дітей. Наявність малолітніх дітей (віком до 3 років) призводить до найбільших втрат у заробітках. Так, у 2007 р. середньомісячний трудовий дохід зайнятих жінок, які мали малолітніх дітей, був на 25,3 \% нижчим у порівнянні із жінками, які мали дітей віком 6-18 років, у 2012 р. цей показник сягнув 39,2 \%. Наявність дітей віком від 3 до 6 років зумовлювала втрати у заробітках жінок близько 8 \% (у 2007 р.) та 12,2 \% (у 2012) порівняно з матерями, які мали старших дітей. Варто наголосити, що в Україні наявність малолітніх дітей (до 3 років) та дітей дошкільного віку практично не позначається на рівні трудового доходу батьків-чоловіків, значущі втрати заробітків несуть лише матері.

Диференціація фінансових втрат / переваг від батьківства за рівнем трудового доходу. Щоб встановити, чи відрізняються втрати від батьківства у працівників з різним рівнем заробітку, ми додатково виділили серед зайнятих дві групи: працівники з низьким доходом, трудовий дохід яких нижчий від офіційного розміру середньомісячної заробітної плати за підсумками відповідного року, та працівники з високим рівнем доходів, трудовий дохід яких перевищує зазначений показник ${ }^{3}$.

Результати розрахунків за економетричною моделлю, представлені у табл. 4, свідчать, що, за інших рівних умов, значущі втрати у заробітку характерні для жінок з малолітніми дітьми та дітьми дошкільного віку, які зайняті на низькооплачуваних роботах, при цьому, як бачимо, відносний розмір цих втрат у динаміці зростає.

Соціально-демографічні характеристики батьків та їхні трудові доходи. Окрім підтвердженої дослідженням гіпотези щодо відмінностей у відносних втратах заробітку, пов'язаних із материнством, для високо- та низько доходних груп жінок, ми висунули також припущення про те, що переваги / втрати трудового доходу можуть диференціюватися для сукупностей батьків / матерів, зайнятих у різних сферах

\footnotetext{
${ }^{2}$ Це цілком узгоджується зі співвідношеннями, отриманими російськими дослідниками за даними вже згадуваного вище [4] лонгітюдного обстеження.

3 За даними Державної служби статистики, у 2007 р. середньомісячна заробітна плата жінок становила 1150 грн, чоловіків - 1578 грн, а у 2012 р. ці показники становили 2661 грн та 3429 грн відповідно.
} 


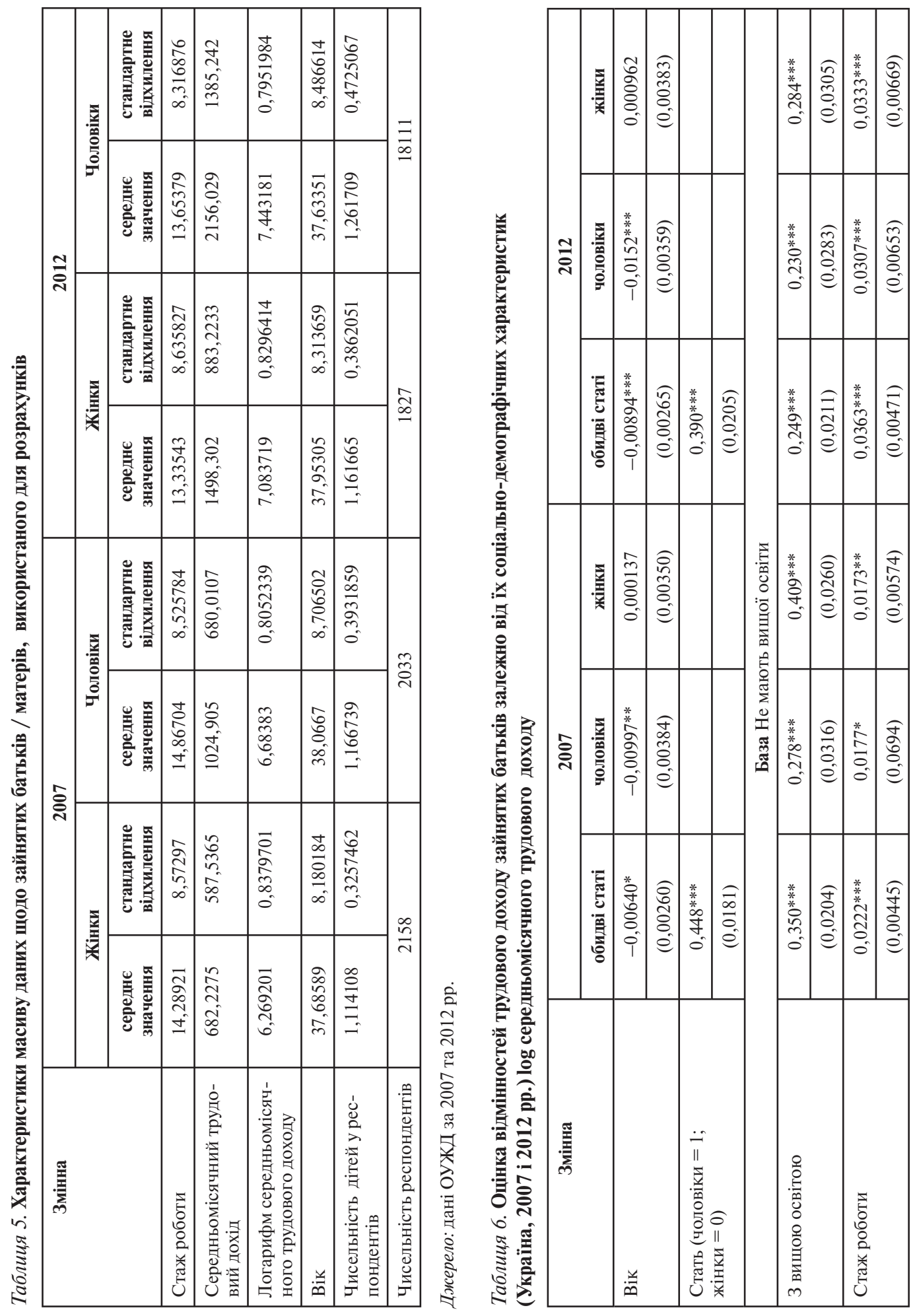




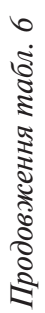

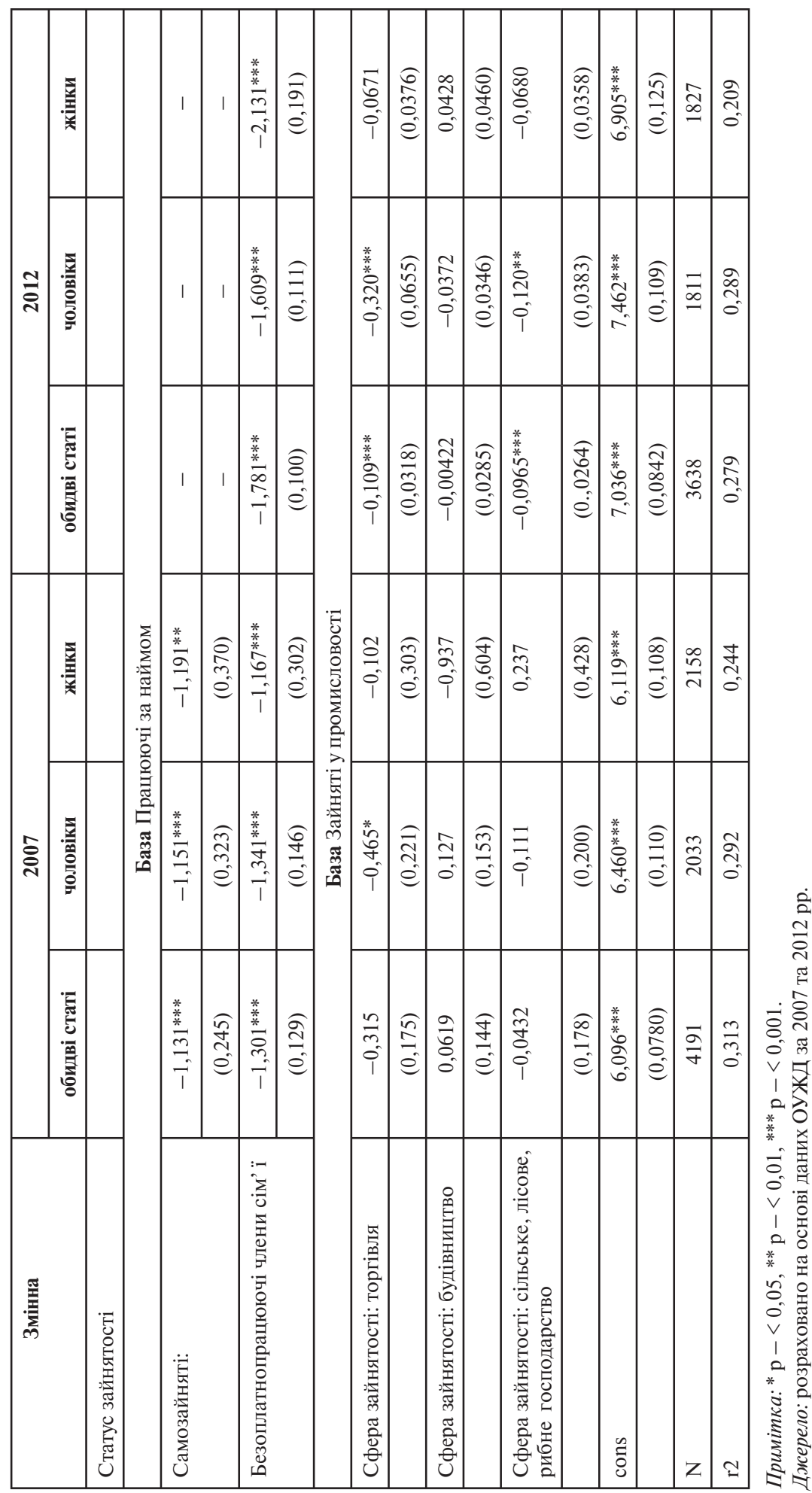


економіки, осіб з різним статусом зайнятості та з різними соціально-демографічними характеристиками. Для перевірки цих гіпотез побудовано економетричну модель за сукупністю зайнятих осіб, які мають дітей (тобто батьків та матерів). Для розрахунків взято дані щодо 4191 осіб за 2007 рік і 3638 осіб за 2012 рік. Описову статистику за цим масивом представлено у табл. 5.

Результати розрахунків продемонстрували значущі переваги високоосвічених батьків щодо рівня трудового доходу порівняно з чоловіками / жінками без вищої освіти, котрі мають дітей. Відповідний розрив у трудових доходах за рівнем освіти відчутніший у жінок, адже фінансові результати їх зайнятості взагалі «тісніше прив'язані до материнства», ніж у чоловіків-батьків. Однак у 2012 р. порівняно $з$ 2007 р. зафіксовано зменшення досліджуваних відмінностей трудового доходу за освітнім рівнем в Україні. Очікувано, що позитивний вплив на рівень трудового доходу чоловіків-батьків та жінок-матерів справляє стаж роботи, причому роль цього чинника у динаміці за досліджувані роки зросла.

Деякі статистично значущі відмінності за рівнем трудового доходу серед батьків / матерів зафіксовано і за ознакою статусу зайнятості: у невигідному становищі тут опиняються самозайняті особи з дітьми, зайнятість яких у вітчизняних умовах часто вирізняється недостатньою стабільністю, вищими ризиками соціальної незахищеності, зосередженням у низькодоходних секторах економіки, а також особи зі статусом безоплатно працюючого члена сім’і. Як це видно з результатів моделювання (табл. 6), секторам економіки, що в Україні переважно акумулюють робочу силу з нижчим освітньо-кваліфікаційним рівнем і відзначаються поширенням негнучкої та соціально незахищеної зайнятості - торгівля, сільське, лісове та рибне господарство тощо притаманні більші відносні втрати трудового доходу працівників, які мають дітей та, відповідно, батьківські обов'язки.

Висновки та рекомендації. Оцінка скорочення заробітків працюючих осіб у зв'язку з батьківством / материнством на матеріалах України з використанням економетричних моделей дала змогу встановити, що найбільші втрати у заробітках жінок пов'язані з наявністю у них малолітніх дітей: зайняті матері дітей віком до 3 років, за інших рівних умов, мали трудові доходи на 25 \% (2007 р.) і на $39 \%$ (2012 р.) менші, ніж жінки з дітьми віком старше 6 років. Якщо скорочення заробітків працюючих матерів у період малоліття дітей видається очікуваним і доволі закономірним, то фінансові втрати зайнятих жінок з дітьми віком від 3 до 6 років, що становили 8-12\% (при цьому у динаміці зросли), не є природними і, ймовірно, зумовлені як наслідками посиленого подвійного - домашнього та виробничого - навантаження жінок-матерів в умовах слабкого розвитку інфраструктури, що полегшувала б догляд за дітьми та домашню працю, так і упередженим ставленням роботодавців до працівників 3 дітьми дошкільного віку (надто - жінок), шо є доволі поширеним у нашій країні.

У результаті моделювання виявлено, що вищий освітній рівень батьків / матерів, за інших рівних умов, убезпечує їх від вагомих втрат заробітку, пов'язаних із батьківством. Показово, що відповідні відмінності щодо трудових доходів осіб з дітьми за рівнем освіти відчутніші у жінок-матерів, ніж у чоловіків-батьків.

Виконані розрахунки фінансових втрат / переваг за різними доходними групами зайнятих свідчать також, що значущі відносні втрати трудового доходу в Україні притаманні матерям з низькими заробітками. Як показує досвід, саме матері, зайняті на низькооплачуваних роботах, через менші альтернативні витрати частіше присвячують свій час вихованню дітей та виконанню інших сімейних обов'язків, погоджуються 
на часткову зайнятість тощо. Натомість батьки / матері із кращими характеристиками людського капіталу (з вищим освітнім рівнем, високооплачувані працівники) навіть у періоди інтенсивного догляду за дітьми та їх виховання частіше вдаються до множинної зайнятості, мають можливість працювати за гнучким графіком, а також делегувати частину батьківських обов'язків найманому персоналу.

Різні види діяльності та позиції в сфері зайнятості в Україні також характеризуються відмінностями щодо втрат заробітків, пов’язаних із батьківством. Найменш дружніми до матерів / батьків із дітьми можна вважати торгівлю, сільське, лісове та рибне господарство - ті сфери, в яких зосереджена робоча сила відносно невисокого освітньо-кваліфікаційного рівня, зі значною часткою неформальної зайнятості, низьким рівнем соціальної захищеності працівників загалом. За ознакою статусу зайнятості у невигідному становищі щодо фінансових втрат від батьківства опиняються самозайняті особи з дітьми та безоплатно працюючі члени сім’і.

Отримані результати дослідження, на наш погляд, свідчать «на користь» активізації у соціальній політиці в Україні такого напряму як створення умов для поєднання зайнятості з батьківством. Цей напрям вже тривалий час є одним із пріоритетних у сімейній політиці низки розвинутих країн і передбачає формування дружнього до працівників з дітьми соціально-трудового середовища, а також досягнення гендерного паритету в основних сферах життєдіяльності. Адже не випадково втрати заробітку, пов'язані з материнством, є мінімальними або й відсутні у країнах з досягнутим високим рівнем гендерної рівності (Данія, Норвегія, Швеція) та й взагалі меншою поширеністю дискримінації за демографічними ознаками (стать, вік, сімейний стан) в основних сферах життя.

Як свідчить досвід формування сімейної політики у названих країнах, немаловажним для підтримання професійно-кваліфікаційного рівня молодих матерів, збереження їхнього заробітку та розвитку кар'єри є забезпечення гнучкості системи відпусток по догляду за малолітніми дітьми, гнучкості умов та режиму праці зайнятих матерів, а також, звісно, належний розвиток якісної дошкільної освіти та виховання (у тому числі з доволі раннього віку дітей). Так, рівень охоплення дітей віком 3-5 років дошкільною освітою в Данії, Норвегії та Швеції становить відповідно майже $98 \%$, близько $97 \%$ та 94 \%, а охоплення дитячими дошкільними закладами дітей у віці до 2 років - 67 \%, 54 \% та 47 \% відповідно. Показово при цьому, що саме у цих країнах, де сформувалось чи не найбільш сприятливе в Європі середовище для материнства / батьківства, стабільно фіксуються найвищі в Європі рівні дітородної активності населення: сумарний показник народжуваності останніх років у Данії становить 1,7 дитини, в Норвегії - 1,8, у Швеції - 1,9 за середньоєвропейського рівня близько 1,6 дитини.

I, насамкінець, вважаємо доречним зауважити, що, крім готовності до можливих фінансових втрат, для народження дітей та реалізації функцій батьківства наразі все ж дуже «...потрібна також щира готовність жертвувати речами дуже особистими, а тому дорожчими за добробут і гроші, такими як, скажімо, час,...такими, яких не можна ані взяти, ані позичити» [1, С. 230]. При цьому, на наш погляд, із подальшим розвитком суспільства роль психологічної мотивації - готовності такого типу - в становленні традицій та поширенні практик відповідального батьківства зростатиме. 


\section{ЛІТЕРАТУРА}

1. Бурдьє П. Практичний глузд / П. Бурдьє. - К. : Український центр духовної культури, 2003. $503 \mathrm{c}$.

2. Arzhenovskiy S. Econometric Estimation of the Wage Penalty for the Motherhood / S. Arzhenovskiy, D. Artamonova. // Applied Econometrics. - 2007. - №7(3). - C. 66-79.

3. Ashwin S. Behind every great man...»: the male marriage wage premium examined qualitatively / S. Ashwin, O. Isupova. // Journal of Marriage and Family. - 2014. - № 76 (1). - C. 37-55.

4. Career Interruptions and Subsequent Wages: A Reexamination Using Swedish Data / J. Albrecht, P. Edin, M. Sundström, S. Vroman. // Journal of Human Resources. - 1999. - № 34. - C. 294-319.

5. Gupta N. Children and Career Interruptions: The Family Gap in Denmark / N. Gupta, N. Smith // Economica. London School of Economics and Political Science. - 2001. - № 69 (276). C. 609-629.

6. Kunze A., Astrid and Matte Ejrnaes. (2004). Wage Dips and Drops around First Birth / A. Kunze, M. Ejrnaes //I. IZA Discussion Paper. 2004. - № No.1011.

7. Livermore T. The Effect of Motherhood on Wages and Wage Growth: Evidence for Australia / T. Livermore, J. Rodgers, P. Siminski. // Special Issue: Selected Papers from the 39th Australian Conference of Economists, Sydney, 27-29 September 2010, 2011. - № 87. - C. 80-91.

8. Loh E. Productivity Differences and the Marriage Wage Premium for White Males / Eng Seng Loh. // Journal of Human Resources. - 1996. - № 31(5). - C. 66-89.

9. Loughran D. Why Wait? The Effect of Marriage and Childbearing on the Wage Growth of Men and Women / D. Loughran, J. Zissimopoulos. // The Journal of Human Resources. - 2009. - № 44 (2). - C. 326-349.

10. Lundberg . S. Parenthood and the Earnings of Married Men and Women / S. Lundberg ., E. Rose // Labour Economics. - 2002. - № 7 (6). - C. 689-710.

11. Nizalova O. Motherhood Wage Penalty in Times of Transition / O. Nizalova, T. Sliusarenko. // IZA Discussion Paper. - 2013. - № 7810.

12. O'Dorchai $S$. Do women gain or lose from becoming mothers? A comparative wage analysis in 20 European countries [Електронний ресурc] / Síle Pádraigín O’Dorchai // RePEc.. - 2006. - Режим доступу до pecypcy: https://dipot.ulb.ac.be/dspace/bitstream/2013/53813/1/RePEc_dul_wpaper_09-11.rs.pdf.

13. Ukrainian Longitudinal Monitoring Survey, 2007.

14. Waldfogel J. The Effect of Children on women's wages / Jane Waldfogel. // American Sociological Review. - 1997. - № 62. - C. 209-217.

15. Whitehouse G. Parenthood and pay in Australia and the UK: evidence from workplace surveys / Gillian Whitehouse // Journal of Sociology. - 2002. - № 38 (4). - C. 381-397.

\section{REFERENCES}

1. Burdie, P. (2003). Praktychnyy hluzd [Practical sence]. Kyiv : Ukrayinskyy tsentr dukhovnoyi kultury [in Ukrinian].

2. Arzhenovskiy, S. \& Artamonova, D. (2007). Econometric Estimation of the Wage Penalty for the Motherhood. Applied Econometrics, 7(3), 66-79 [in English].

3. Ashwin, S. \& Isupova, O. (2014). Behind every great man...: the male marriage wage premium examined qualitatively. Journal of Marriage and Family, Vol. 76(1), 37-55 [in English].

4. Albrecht, J., Edin, P., Sundström, M. \& Vroman, S. (1999). Career Interruptions and Subsequent Wages: A Reexamination Using Swedish Data. Journal of Human Resources, 34, $294-319$ [in English].

5. Gupta, N. \& Smith, N. (2001). Children and Career Interruptions: The Family Gap in Denmark. Economica. (Vol. 69 (276), 609-629). London School of Economics and Political Science [in English].

6. Kunze, A. \& Ejrnaes, M. (2004). Wage Dips and Drops around First Birth. IZA Discussion Paper, 1011 [in English].

7. Livermore, T., Rodgers, J. \& Siminski, P. (2011). The Effect of Motherhood on Wages and Wage Growth: Evidence for Australia. Special Issue: Selected Papers from the 39th Australian Conference of Economists (27-29 September 2010). (Vol. 87, 80-91). Sydney [in English].

8. Loh, E. (1996). Productivity Differences and the Marriage Wage Premium for White Males. Journal of Human Resources, Vol. 31(5), 66-89 [in English]. 
9. Loughran, D. \& Zissimopoulos, J. (2009). Why Wait? The Effect of Marriage and Childbearing on the Wage Growth of Men and Women. Journal of Human Resources, Vol. 44(2), 326-349 [in English].

10. Lundberg, S. \& Rose, E. (2002). Parenthood and the Earnings of Married Men and Women. Labour Economics, Vol. 7(6), 689-710 [in English].

11. Nizalova, O., Sliusarenko, T. (2013). Motherhood Wage Penalty in Times of Transition. IZA Discussion Paper, 7810 [in English].

12. O'Dorchai, S. (2006). Do women gain or lose from becoming mothers? A comparative wage analysis in 20 European countries. dipot.ulb.ac.be. Retrieved from https://dipot.ulb.ac.be/dspace/bitstream/2013/53813/1/RePEc_dul_wpaper_09-11.rs.pdf [in English].

13. Ukrainian Longitudinal Monitoring Survey (2007). [in English].

14. Waldfogel, J. (1997). The Effect of Children on women's wages. American Sociological Review, Vol. 62, 209-217 [in English].

15. Whitehouse, G. (2002). Parenthood and pay in Australia and the UK: evidence from workplace surveys. Journal of Sociology, Vol. 38 (4), 381-397 [in English].

Стаття надійшла до редакції журналу 10.04.2016. 